Колосок Андрій, кандидат економічних наук, доцент, Східноєвропейський національний університет імені Лесі Українки, кафедра економіки, безпеки та інноваційної діяльності підприємства, м. Луцьк, ORCID ID 0000-0001-9167-5430, e-mail: kolosok.andrew@eenu.edu.ua

Буднік Світлана, кандидат педагогічних наук, старший викладач, Східноєвропейський національний університет імені Лесі Українки, кафедра теорії і методики початкової освіти, м. Луцьк, ORCID ID 0000-0002-7859-6153,

https://doi.org/10.29038/2411-4014-2019-04-109-116 e-mail: akva_svitlanka@ukr.net

\title{
СОЦІАЛЬНА ВІДПОВІДАЛЬНІСТЬ В АКВАРІУМНОМУ БІЗНЕСІ: ЕКОНОМІЧНІ ТА ПЕДАГОГІЧНІ АСПЕКТИ
}

У статті розглянуто економічні та педагогічні аспекти соціальної відповідальності акваріумного бізнесу, запропоновано пріоритетні напрями його розвитку з метою підтримки та оптимізації екологічного виховання учнів й студентської молоді. Обгрунтовано значення соціальної відповідальності акваріумного бізнесу для створення в закладах освіти відповідної навчально-матеріальної бази: куточків живої природи, кабінетів акваріумістики; та проведення тренінгів, майстер-класів, дитячих та юнацьких конкурсів з аквадизайну.

Наукова новизна дослідження полягає у визначенні сутності соціальної відповідальності в акваріумному бізнесі, їі складових та впливу на учнівську молодь через інтерактивні форми екологічного виховання.

Ключові слова: соціальна відповідальність бізнесу, інтерактивні форми екологічного виховання, аквадизайн.

Колосок Андрей, кандидат экономических наук, доцент, Восточноевропейский национальный университет имени Леси Украинки, кафедра экономики, безопасности и инновационной деятельности предприятия, г. Луцк

Будник Светлана, кандидат педагогических наук, старший преподаватель, Восточноевропейский национальный университет имени Леси Украинки, кафедра теории и методики начального образования г. Луцк

\section{СОЦИАЛЬНАЯ ОТВЕТСТВЕННОСТЬ В АКВАРИУМНОМ БИЗНЕСЕ: ЭКОНОМИЧЕСКИЕ И ПЕДАГОГИЧЕСКИЕ АСПЕКТЫ}

В статье рассмотрены экономические и педагогические аспекты социальной ответственности аквариумного бизнеса, предложены приоритетные направления его развития с целью поддержки и оптимизации экологического воспитания учащихся и студенческой молодежи. Обосновано значение социальной ответственности аквариумного бизнеса для создания в учебных заведениях соответствующей учебно-материальной базы: уголков живой природы, кабинетов аквариумистики; и проведении тренингов, мастер-классов, детских и юношеских конкурсов с аквадизайна.

Научная новизна исследования заключается в определении сущности социальной ответственности в аквариумном бизнесе, ее составляющих и влияния на учащуюся молодежь через интерактивные формы экологического воспитания.

Ключевые слова: социальная ответственность бизнеса, интерактивные формы экологического воспитания, аквадизайн. 


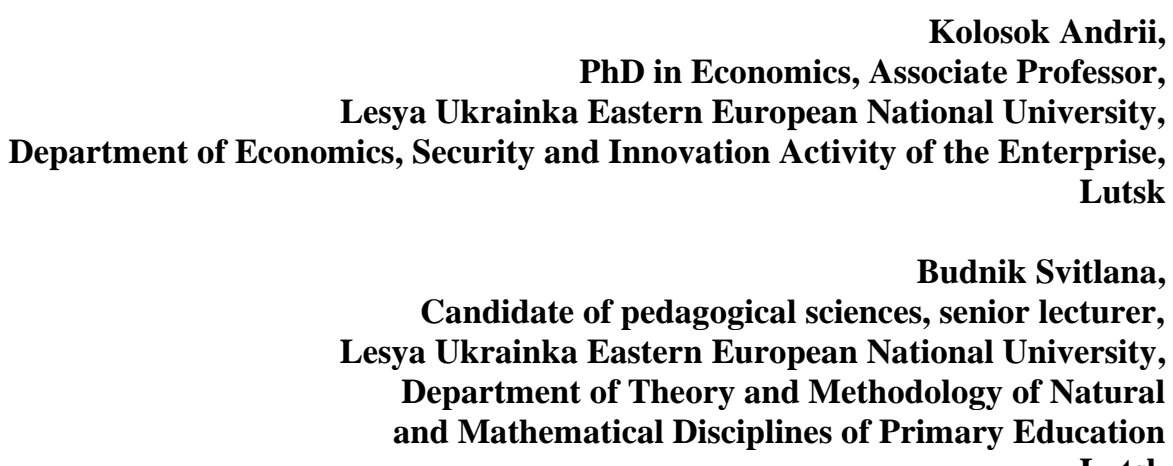

Lutsk

\section{SOCIAL RESPONSIBILITY IN AQUARIUM BUSINESS: ECONOMIC AND PEDAGOGICAL ASPECTS}

Introduction. The cooperation of Ukrainian aquarium business with educational institutions, the desire to develop students' environmental awareness through interactive forms of education form the relevance of the research topic.

The purpose of the article. The purpose of the article is to study theoretical and practical principles of economic and pedagogical aspects of aquarium business social responsibility, to formulate recommendations for improvement and priorities of development of socially responsible approach in aquarium segment of economy.

Results. The article deals with economic and pedagogical aspects of social responsibility of aquarium business in Ukraine. The evolution of the concept of "social responsibility" is investigated, the domestic and foreign definitions of this scientific category are analyzed, the own vision of economic and pedagogical aspects of social responsibility of aquarium business is formed. The value of social responsibility of aquarium business for creation in educational establishments of the corresponding educational and material base: nature study corner, offices of aquarium is substantiated.

According to the results of the research, it is defined that interactive forms and methods of training in aquarium business, including giving master classes, competitions for children and youth in aquaristics and the art of aquadesign contribute to the formation of personality ecological culture, development of cognitive activity more than traditional forms and methods of teaching; teach pupils and students the ability to express and argue their opinions; teach valuable quality - to be able to listen to each other, to act as a critic; contribute to the mastery of fundamental environmental knowledge; form beliefs; learn to predict the effects of anthropogenic impact; model possible environmental situations; call for vigorous environmental activities.।

Conclusions. The priority areas for the development of the social responsibility of the aquarium business include: sponsorship and charitable assistance in creating in the educational institutions an appropriate educational and material base: place of wildlife, aquarium rooms, etc.; improving the forms and methods of pupils and students environmental education; active involvement of representatives of aquarium brands in cooperation with schools, institutions of additional education and universities on conducting lectures, presentations, seminars, trainings, master classes, children's and youth competitions in aquarium and aquadesign; the formation of motives for a responsible attitude to nature, the desire to learn more about it, to increase its wealth.

Key words: business social responsibility, interactive forms of environmental education, aquadesign.

Постановка проблеми та ії значення. Катастрофічний стан навколишнього середовища, що нині вже істотно визначає здоров’я людей, тривалість їхнього життя, саму можливість стабільного існування, спонукає до дослідження та роздумів науковців. До проблеми природокористування звертаються екологи, біологи, географи, історики, політичні діячі, письменники, економісти й ін.

Важливо, щоб сьогодні всі, і дорослі, і діти, стали на шлях співробітництва 3 природою. Тому одними із основних завдань у сучасній школі є екологічне виховання підростаючого покоління, формування нового екологічного світогляду.

Співпраця українського акваріумного бізнесу із освітніми закладами, прагнення розвивати екологічну свідомість учнів через інтерактивні форми виховання формують актуальність теми дослідження. 
Аналіз останніх досліджень і публікацій. Дослідження проблем соціальної відповідальності бізнесу проводиться у світовій літературі, починаючи із середини минулого століття. За цей період опубліковано значну кількість наукових праць вітчизняних й іноземних учених стосовно цієї теми. Серед них - О. Гогуля [5], К. Десятник [2], А. Колосок [3], А. Колот [12], Ю. Мельник [9] та ін.

Однак, незважаючи на наявність значної кількості наукових праць у цій сфері, проблеми соціальної відповідальності потребують подальшого їх вивчення. Зокрема, залишаються недостатньо розробленими теоретико-методологічні питання та практичні рекомендації з формування екологічної культури учнів і студентів та регулювання економічних й педагогічних аспектів соціальної відповідальності акваріумного бізнесу.

Мета і завдання статті. Мета статті - вивчення теоретичних і практичних засад економічних та педагогічних аспектів соціальної відповідальності акваріумного бізнесу, формування рекомендацій щодо вдосконалення й пріоритетів розвитку соціально відповідального підходу в акваріумному сегменті економіки. Відповідно до поставленої мети, завданнями дослідження визначимо:

- розкрити сутність соціальної відповідальності бізнесу;

- дослідити інтерактивні форми екологічного виховання.

Викладення основного матеріалу та обгрунтування отриманих результатів дослідження. Соціальна відповідальність все більшою мірою проникає в усі сфери соціально-економічного життя країни. Це зумовлено як впливом розвинених країн, так і внутрішніми реформами, що відбуваються в державі.

Надзвичайно важливий розвиток соціальної відповідальності в акваріумному бізнесі, оскільки це пов'язано з екологічним вихованням дітей.

Ми підтримуємо думку С. Совгіри, що починати екологічне виховання треба з дошкільного віку й продовжувати в шкільні роки, оскільки в цей час набуті знання можуть надалі перетворитися в міцні переконання [10, с. 77]. Тому в школах велика увага приділяється екологічній роботі та природоохоронній діяльності. У нашому дослідженні ми детальніше розглянемо співпрацю освітніх закладів і представників акваріумного бізнесу.

Невід’ємною особливістю успішної бізнес-стратегії акваріумних підприємств є дотримання принципів соціальної відповідальності, найважливішими 3 котрих $є$ систематичність і цільова спрямованість, завдяки чому відбувається зміцнення репутації підприємства та мінімізація негативних наслідків кризових ситуацій, що виникають у процесах виробництва.

Яскравим прикладом соціального відповідального підприємства в акваріумному бізнесі $\epsilon$ компанія торговельної марки «Теtra». Так, 20 жовтня в Миколаївській гімназії № 4 відбулись обласні змагання юних акваріумістів за підтримки обласного науково-екологічного центру учнівської молоді та торговельної марки «Tetra». До гімназії прибули учасники з 21 навчального закладу міста Миколаєва та Миколаївської області. Програма заходу складалася з двох турів. У першому брали участь усі команди, котрі прибули на конкурс, де перевіряли їхні знання з іхтіології. У другий тур потрапили 12 команд, що за підсумками І-го, набрали найбільшу кількість балів. Командам потрібно було оформити акваріум і правильно заселити в нього акваріумних рибок.

Проте на ті команди, які не вийшли до II туру, чекала цікава програма від спонсорів заходу компанії «Теtra»: перегляд галереї акваріумних рибок та лекція «Догляд за акваріумом». Також треба зазначити, що дитяча акваріумістика в Миколаєві - одна 3 найсильніших в Україні. Цей факт підтверджується рішенням провести в Миколаєві Всеукраїнський конкурс-виставку дитячої акваріумістики [11].

Так, 5-6 листопада 2017 р. на базі Миколаївської гімназії № 4 відбувся 5-й регіональний відкритий конкурс юних акваріумістів i, як інформує департамент освіти і науки Миколаївської ОДА, «Від спонсорів конкурсу, ТМ «Природа», ТМ «Тетра», ТМ «Акваель», переможці отримали акваріуми ТМ, 65 літрів, 54 літри», а Миколаївський зоопарк запросив учасників конкурсу, гостей міста Миколаєва на екскурсію. Також учасники й гості конкурсу мали можливість відвідати виставку тварин й акваріумних рибок Дитячої зоогалереї «Фенікс» [7].

Корисним є досвід групи компанії «Сузір'я», ТМ «Природа», TM «Tetra», TM «AQUAEL», які розробили серію дитячих конкурсів 3 аранжування акваріумів на теми: «Новорічна казка в акваріумі», «Зимова казка в акваріумі», «Весняна казка в акваріумі» 3 метою популяризації дитячої 
акваріумістики й систематично проводять в акваріумних студіях, у закладах позашкільної освіти України [6].

Цікаво, що перший приклад є спонсорською допомогою, а другий - безпосередньо соціальною відповідальністю. Від першого варіанта підприємство не матиме жодного зиску, окрім прихованої реклами. А проведені цікаві заходи 3 дитячої акваріумістики, безкоштовні майстер-класи 3 облаштування акваріума й подарунки від групи компанії «Сузір'я», ТМ «Природа», ТМ «Теtra», ТМ «AQUAEL» для дітей, позитивно вплинуть на навчання та екологічне виховання учнів, підвищать імідж компанії «Сузір'я», TM «Природа», TM «Tetra», TM «AQUAEL» у цілому та закладуть основи для подальшого розвитку підприємств.

Фінал дитячого конкурсу аранжування акваріумів «Aquaterra Show-2019», який проводився задля популяризації акваріумної справи сприяння розвитку дитячої акваріумістики в Україні (2019 p. м. Київ), до участі були запрошені діти-переможці регіональних дитячих конкурсів зі створення аквадизайну. Цей захід відбувся завдяки співпраці групи компанії «Сузір'я», ТМ «Природа», ТМ «Tetra», TM «AQUAEL», TM «AquaLighter» [14].

На нашу думку, потрібно додати ще дуже цікаву інформацію щодо соціальної відповідальності компанії торговельної марки «Rikka», що спеціалізується на виготовленні акваріумної хімії й не лише [13]. Це підприємство підтримало організаторів обласної виставки-конкурсу з акваріумістики та мистецтва аквадизайну «AQUASCAPE», яку проведено в грудні 2018 р. на базі Волинського обласного еколого-натуралістичного центру для студентів педагогічних спеціальностей, вихованців закладів позашкільної освіти еколого-натуралістичного спрямування, учнів закладів освіти Волині. Керівник торговельної марки «Rikka» подарував препарати і кондиціонери, тести для акваріумної води для переможців та усіх учасників обласної виставки-конкурсу з акваріумістики й мистецтва аквадизайну «AQUASCAPE» [1].

Із метою популяризації дитячої акваріумістики та екологічного виховання систематично менеджерами вищезазначених акваріумних компаній проводиться роз'яснювально-інформаційна, діагностико-прогностична робота зі школярами за допомогою таких традиційних та інтерактивних форм як лекції-презентації; бесіди; виставки-конкурси; майстер-класи; зустрічі $з$ фахівцями акваріумної справи. Ефективними виявилися такі інтерактивні форми екологічного виховання, як виставка-конкурс і майстер-клас (див. табл.1).

Для пропаганди екологічної інформації та з метою формування пізнавальних інтересів учнів до акваріумної справи керівники гуртка з акваріумістики розробляють різноманітні екологічні проекти, закладають підводні сади, проводять конкурси екоплакатів, організовують конкурси 3 акваріумістики та мистецтва аквадизайну. Наприклад, подамо описи композицій прісноводних акваріумів учасників обласної виставки-конкурсу аранжування акваріумів «Волинь моя».

Для композиції на тему «Поліський затишок» ми використали рослини (валіснерію, анубіас, кладофору кулясту, папороть таїландську, а також мох яванський) і декорації, серед котрих дерев'яна коряга й керамічна хатинка з отворами.

Поліські краєвиди неможливо уявити без дерев, серед яких губляться цілі села. Тому центром нашої композиції є «дуб», для оформлення якого використано яванський мох і карликовий анубіас. В основі дуба розміщено таїландську папороть. Навколо дерева посаджено валіснерію 3 прямим листям, яка відображає зелену травичку на лісовій галявині. А також анубіас з кроною, схожою на осику. Крилоподібна папороть дуже подібна до папороті орляка, котра є обов'язковою для наших лісів. Кладофора куляста символізує купини моху зозулиного льону, якого теж багато в наших лісах.

I ще одна цікава композиція - це «Острів на болоті». Для іiі оформлення використано такі рослини, як анубіас, папороть таїландська, криптокорина і яванський мох. Із декорацій задіяно дерев'яну корягу, глечик, скляні кульки, шматочки бурштину та кілька нереальних об'єктів.

Сам острів розміщено в одній половині акваріума у вигляді підвищення, а іншу частину зроблено нижчою - це так зване болото.

На острові ми розмістили «дерева», сформовані з високих анубіасів, і корягу, оформлену 3 допомогою яванського моху під хвойні рослини, які переважають у нашій місцевості. В основі такої сосни росте таїландська папороть. Острівну галявину прикрашено «старим пнем», на якому вже виросла нова рослина, що характерно для вітчизняного. Криптокорини на острові символізують кущі, адже наші ліси багатоярусні. 
Навколо острова простягнулося болото, яке можна відрізнити за червоним кольором грунту, оскільки вода в болоті переважно коричнево-червоного кольору. Типовими рослинами лісового болота $€$ образки болотні, роль яких у нашій композиції відіграють карликовий анубіас, а також аїр болотний (його аналогом $є$ валіснерія з прямим листям). На межі острова й болота розміщені скляні кульки, які вказують на високу вологість цієї місцевості. Шматочки бурштину нагадують про природне багатство Поліського краю.

Ефективні інтерактивні форми екологічного виховання *

\begin{tabular}{|c|c|c|}
\hline Компанії & Виставки-конкурси & Майстер-класи \\
\hline TM «Sera» & $\begin{array}{l}\text { Сімейний конкурс: «Моя маленька казка», креативний конкурс } \\
\text { аранжування акваріума для дітей «Як проходить дитинство» } \\
\text { (м. Дніпро); сімейний конкурс «7 Я - одна перемога» (м. Дніпро); } \\
\text { перша міська дитяча виставка-конкурс акваріумів (м. Вінниця); } \\
\text { конкурс «П’ять рук - одна перемога» (м. Вінниця); Міжнародний } \\
\text { конкурс аранжування акваріумів, об'ємом } 10 \text { літрів «Мікроакваріум» } \\
\text { (м. Одеса, м. Київ). }\end{array}$ & $\begin{array}{l}\text { Запуск мого } \\
\text { першого } \\
\text { акваріума } \\
\text { (м. Дніпро) }\end{array}$ \\
\hline $\begin{array}{l}\text { TM } \\
\text { «COLLAR» }\end{array}$ & $\begin{array}{lcccr}\text { Конкурс } & 3 \text { аквадизайну } \text { «Мій креативний акваріум» } & \text { (м. Луцьк); } \\
\text { Перший } & \text { чемпіонат } & \text { України дитячо-юнацького } & \text { конкурсу } \\
\text { аранжування акваріумів Aquaterra Show-2018 (м. Київ). } & \end{array}$ & $\begin{array}{l}\text { Облаштування } \\
\text { декоративного } \\
\text { акваріума для } \\
\text { Betta splendes } \\
\text { (м. Луцьк) }\end{array}$ \\
\hline TM «Tetra» & $\begin{array}{l}\text { Дитячий конкурс зі створення аквадизайну «Aqua Fan Kids» (м. } \\
\text { Івано-Франківськ, м. Одеса, м. Маріуполь, м. Дніпро, м. Київ); } \\
\text { дитячий конкурс } 3 \text { аранжування акваріумів «Новорічна казка в } \\
\text { акваріумі», дитячий конкурс } 3 \text { аранжування акваріумів «Зимова казка } \\
\text { в акваріумі», дитячий конкурс } 3 \text { аранжування акваріумів «Весняна } \\
\text { казка в акваріумі»; регіональний конкурс юних акваріумістів (м. } \\
\text { Миколаїв); дитячий конкурс по оформленню акваріумів } \\
\text { (м. Миргород); новорічний конкурс «Виграй акваріум від ТМ «Теtra» } \\
\text { та конкурс «Теtra-селфі-Новий рік». }\end{array}$ & $\begin{array}{l}\text { Мій перший } \\
\text { акваріум; } \\
\text { облаштування } \\
\text { акваріума } \\
\text { живими } \\
\text { рослинами }\end{array}$ \\
\hline TM «Rikka» & $\begin{array}{l}\text { Обласна виставка-конкурс } 3 \text { акваріумістики та мистецтва } \\
\text { аквадизайну «AQUASCAPE» для студентів педагогічних } \\
\text { спеціальностей, вихованців закладів позашкільної освіти еколого- } \\
\text { натуралістичного спрямування, учнів закладів освіти Волині (м. } \\
\text { Луцьк). }\end{array}$ & \begin{tabular}{lr} 
Запуск & \\
акваріума від А \\
до Я & \multicolumn{1}{c}{ Я } \\
використанням \\
продукції & TM \\
«Rikka» & (м. \\
Луцьк) &
\end{tabular} \\
\hline TM «Ptero» & $\begin{array}{l}\text { Дитячий конкурс } з \text { аквадизайну «Мій креативний акваріум», обласна } \\
\text { виставка-конкурс } 3 \text { аранжування акваріумів «Осінь-2017» та обласна } \\
\text { виставка-конкурс } 3 \text { аранжування акваріумів «Волинь моя» } \\
\text { (м. Луцьк). }\end{array}$ & $\begin{array}{l}\text { Облаштування } \\
\text { декоративного } \\
\text { акваріума для } \\
\text { Betta splendes } \\
\text { (м. Луцьк) }\end{array}$ \\
\hline $\begin{array}{l}\text { TM } \\
\text { «AquaEl» }\end{array}$ & $\begin{array}{l}\text { Дитячий конкурс зі створення аквадизайну «Aqua Fan Kids». 8-й } \\
\text { Міжнародний конкурс аранжування акваріумів, об’ємом } 10 \text { літрів } \\
\text { «Мікроакваріум» (м. Одеса); регіональний конкурс юних } \\
\text { акваріумістів (м. Миколаїв); виставка-конкурс наноквваріумів } \\
\text { (м. Ужгород); виставка акваріумних риб «Барви гупі» (м. Львів). }\end{array}$ & $\begin{array}{l}\text { Облаштування } \\
\text { акваріума } \\
\text { живими } \\
\text { рослинами та } \\
\text { натуральними } \\
\text { декораціями } \\
\text { (м. Луцьк) } \\
\end{array}$ \\
\hline
\end{tabular}

* Джерело: Власна розробка авторів 
Завдяки даним акваріумним композиціям учні вчаться акваскейпингу, формують біологічно стійкі водойми, засвоюють нові знання та вміння у цікавій формі інтерактивного екологічного виховання та формують свою національну ідентичність.

Висновки i перспективи подальших досліджень. За результатами дослідження, ми стверджуємо що соціальна відповідальність акваріумного бізнесу - це цілеспрямована, систематична й добровільна участь акваріумних компаній у розробці та реалізації заходів природоохоронного характеру, укладення коштів в екологічні проекти, формування відповідальної свідомості суспільства шляхом навчально-просвітницької роботи 3 дітьми в акваріумних гуртках $\mathrm{i}$ відповідальність акваріумного бізнесу за результати своєї виробничої діяльності перед місцевими громадами й суспільством у цілому заради покращення стану навколишнього середовища та прихованої реклами власної продукції.

Щодо педагогічних аспектів соціальної відповідальності в акваріумному бізнесі, то потрібно відзначити що інтерактивні форми й методи навчання з акваріумної справи сприяють формуванню екологічної культури особистості, розвитку пізнавальної активності сильніше, ніж традиційні форми та методи навчання; навчають учнів і студентів уміння висловлювати та аргументувати свої думки; формують цінну якість - уміти слухати один одного, виступати в ролі критика; сприяють оволодінню фундаментальними екологічними знаннями; виховують переконання, а також уміння передбачати наслідки антропогенного впливу; моделювати можливі екологічні ситуації; закликають до активної природоохоронної діяльності.

Таким чином, проведений вище аналіз економічних і педагогічних аспектів соціальної відповідальності в акваріумному бізнесі показує, що соціальна відповідальність у цій сфері може проявлятися різноманітними акціями, заходами, спонсорською допомогою, благодійництвом та ін.

Найвагомішими причинами, що стримують становлення соціальної відповідальності акваріумного бізнесу в Україні, є законодавча неврегульованість та відсутність податкового заохочення.

Отже, до пріоритетних напрямів розвитку соціальної відповідальності акваріумного бізнесу потрібно віднести спонсорську й благодійну допомогу у створенні в закладах освіти відповідної навчально-матеріальної бази - куточків живої природи, кабінетів акваріумістики та ін.; активне залучення представників акваріумних торговельних марок до співпраці зі школами, закладами позашкільної освіти й закладами вищої освіти щодо проведення лекцій-презентацій, пізнавальних семінарів, навчальних тренінгів, майстер-класів, дитячих і юнацьких конкурсів з акваріумістики та мистецтва аквадизайну; формування й мотивацію відповідального ставлення до природи, прагнення глибше пізнавати та примножувати іiї багатства.

Перспективи подальших досліджень убачаємо в подальшому пошуку актуальних способів взаємодії закладів освіти з представниками акваріумного бізнесу з метою екологічного виховання учнівської та студентської молоді.

\section{Джерела та література}

1. «AQUASCAPE»: у Луцьку оголосили результати обласної виставки 3 акваріумістики. URL: https://volynua.com/posts/aquascape-u-lutsku-ogolosili-rezultati-oblasnoi-vistavki-z-akvariumistiki-foto ～(дата звернення : 25.10.2019).

2. Буднік С., Десятник К. Екологічне виховання школярів та студентської молоді у взаємодії 3 представниками акваріумного бізнесу. Педагогічний часопис Волині. Луцьк , 2018. № 4 (11). С. 106-111.

3. Колосок А.М. Теоретичний аспект соціальної відповідальності бізнесу. Економічний часопис. Луцьк, 2015. № 4. C. 64-67.

4. Вдячність торгівельній марці «COLLAR» за спонсорську допомогу у проведенні дитячого конкурсу з аквадизайну «Мій креативний акваріум». URL: http://voenc.lutsk.ua/index.php/novyny/169-konkurs-iunykhakvariumistiv-mii-kreatyvnyi-akvarium (дата звернення : 25.10.2019).

5. Гогуля О. П., Кудінова І. П. Теоретичні аспекти соціальної відповідальності аграрного бізнесу. Науковий вісник Національного університету біоресурсів і природокористування Украйни. Серія: Економіка, аграрний менеджмент, бізнес. 2013. Вип. 181(2). С. 101-105.

6. Дитячий конкурс зі створення аквадизайну «Aqua Fan Kids». URL: https://www.facebook.com/events/381971156037942/403836213851436/?notif_t=admin_plan_mall_activity\&notif_id =1571841358701041 (дата звернення : 26.10.2019). 
7. Запрошення учнів гімназії спонсорів торгівельної марки «Тетра» на першу Міжнародну виставку сучасної акваріумістики та терраріумістики «Акватерра шоу». URL: http://pedpresa.ua/172536-yuni-akvariumistyzmagalysya-na-mykolayivshhyni.html (дата звернення : 26.10.2019).

8. Конкурс 3 аквадизайну «Мій креативний акваріум» у BOEHЦ. URL: http://voenc.lutsk.ua/index.php/novyny/169-konkurs-iunykh-akvariumistiv-mii-kreatyvnyi-akvarium (дата звернення : 27.10.2019).

9. Мельник Ю. М. Пріоритети розвитку соціальної відповідальності аграрного бізнесу. Економічний форум. 2014. № 4. С. 263-269.

10. Совгіра С. В. Принцип наступності - важливий чинник екологічної освіти. Науковий вісник Уманського державного університету імені Павла Тичини. Серія: Педагогіка. 2014. Вип. 118(2). С. $76-105$.

11. Соціальна відповідальність торгівельної марки «Тетра». URL: https://www.facebook.com/groups/1670732199819185/?fref=ts (дата звернення : 28.10.2019).

12. Соціальна відповідальність: теорія і практика розвитку: монографія / А. М. Колот та ін. ; за наук. ред. А. М. Колота. Київ : КНЕУ, 2012. 504 с.

13. Торгівельна марка «Rikka». URL: https://www.facebook.com/pg/tmrikka/about/?ref=page_internal (дата звернення : 28.10.2019).

14. Четверта Міжнародна виставка сучасної акваріумістики та тераріумістики «Акватерра шоу». URL: http://www.aquaterrashow.com.ua (дата звернення : 29.10.2019).

\section{References}

1. «AQUASCAPE»: u Lutsku oholosyly rezultaty oblasnoi vystavky z akvariumistyky [«AQUASCAPE»: the results of the regional aquarium exhibition in Lutsk have announced]. Retrieved from https://volynua.com/posts/aquascape-u-lutsku-ogolosili-rezultati-oblasnoi-vistavki-z-akvariumistiki-foto

2. Budnik, S., Desiatnyk, K. (2018). Ekolohichne vykhovannia shkoliariv ta studentskoi molodi u vzaiemodii z predstavnykamy akvariumnoho biznesu [Environmental education of schoolchildren and student youth in the interaction with representatives of aquarium business]. Pedahohichnyi chasopys Volyni - Pedagogical Journal Volyn, 4(11), 106-111 [In Ukrainian].

3. Kolosok, A. M. (2015) Theoretical aspect socialnoi vidpovidalnosti biznesu [Theoretical Aspect of Social Responsibility of Business]. Ekonomichnyi chasopys - Economic Journal of Lesia Ukrainka Eastern European National University, 4, 64-67 [In Ukrainian].

4. Vdiachnist torhivelnii martsi «COLLAR» za sponsorsku dopomohu u provedenni dytiachoho konkursu $\mathrm{z}$ akvadyzainu «Mii kreatyvnyi akvarium» [Acknowledgment to the COLLAR trademark for sponsorship of the «My creative Aquarium» Aquarium Design Competition for children]. Retrieved from http://voenc.lutsk.ua/index.php/novyny/169-konkurs-iunykh-akvariumistiv-mii-kreatyvnyi-akvarium

5. Hohulia, O. P., Kudinova, I. P. (2013). Teoretychni aspekty sotsialnoi vidpovidalnosti ahrarnoho biznesu [Theoretical aspects of social responsibility of agrarian business]. Naukovyi visnyk Natsionalnoho universytetu bioresursiv i pryrodokorystuvannia Ukrainy. Ser. Ekonomika, ahrarnyi menedzhment, biznes - Scientific Bulletin of the National University of Life and Environmental Sciences of Ukraine. Ser. Economics, agrarian management, business, 181(2), 101-105 [In Ukrainian].

6. Dytiachyi konkurs zi stvorennia akvadyzainu «Aqua Fan Kids» [Children's Aqua Design Competition «Aqua Fan Kids»]. $\quad$ Retrieved from https://www.facebook.com/events/381971156037942/403836213851436/?notif_t=admin_plan_mall_activity\&notif_id $=1571841358701041$

7. Zaproshennia uchniv himnazii vid sponsoriv torhivelnoi marky «Tetra» na pershu Mizhnarodnu vystavku suchasnoi akvariumistyky ta terrariumistyky «Akvaterra shou» [Invitation for students of a gymnasium from sponsors of the Tetra trademark to the first International Aquarium and Terrarium Exhibition «Aquaterra Show»]. Retrieved from http://pedpresa.ua/172536-yuni-akvariumisty-zmagalysya-na-mykolayivshhyni.html

8. Konkurs z akvadyzainu «Mii kreatyvnyi akvarium» u VOENTs [Aqua Design Competition «My Creative Aquarium» at VRESC]. Retrieved from http://voenc.lutsk.ua/index.php/novyny/169-konkurs-iunykh-akvariumistivmii-kreatyvnyi-akvarium

9. Melnyk, Yu. M. (2014). Priorytety rozvytku sotsialnoi vidpovidalnosti ahrarnoho biznesu [Priorities of development of social responsibility of agrarian business]. Ekonomichnyi forum - Economic Forum, 4, 263-269 [In Ukrainian].

10. Sovhira, S. V. (2014). Pryntsyp nastupnosti - vazhlyvyi chynnyk ekolohichnoi osvity [The principle of continuity is an important factor in environmental education]. Naukovyi visnyk Umanskoho derzhavnoho universytetu imeni Pavla Tychyny. Ser. Pedahohika. - Scientific Bulletin of Pavel Tychyna Uman State University. Ser. Pedagogy, 118(2), 76-105 [In Ukrainian]. 
11. Sotsialna vidpovidalnist torhivelnoi marky «Tetra» [Social responsibility of Tetra trademark]. Retrieved from https://www.facebook.com/groups/1670732199819185/?fref=ts

12. Kolota, A. M., Hrishnova, O. A. et al. (2012). In A. M. Kolot (Ed.). Sotsialna vidpovidalnist: teoriia $i$ praktyka rozvytku: monohrafiia [Social responsibility: theory and practice of development]. Kyiv: KNEU [In Ukrainian].

13. Torhivelna marka «Rikka» [Trademark https://www.facebook.com/pg/tmrikka/about/?ref=page_internal

14. Chetverta Mizhnarodna vystavka suchasnoi akvariumistyky ta terariumistyky «Akvaterra shou» [Fourth International Exhibition of Modern Aquarium and Terrarium «Akvaterra show»]. Retrieved from http://www.aquaterrashow.com.ua

Стаття надійшла до редакції 10.11.2019 р.

УДК 339.152

Makara Oksana, doctor of economics, Prof. Department of Finance and Credit, Lesya Ukrainka Eastern European National University, Lutsk, e-mail: ok302008@ukr.net

Lialiuk Alla, Associate Professor, Economics and Security of Enterprise Department, Lesya Ukrainka East European National University, Associate Professor, Ph.D. in Economics. Lutsk, ORCID ID: 0000-0002-4889-0511 e-mail: allalyalyuk@gmail.com

Panasiuk Yurii 3rd year student of the Faculty of Economics and Management, Lesia Ukrainka East European National University, Lutsk,. e-mail: yura@macaw.me

\author{
https://doi.org/10.29038/2411-4014-2019-04-116-124
}

\title{
MODERN TECHNOLOGIES OF MARKETING INTELLIGENCE
}

The purpose of the article is to explore the use of the latest technologies in marketing intelligence, and to offer a vision of its use without harming the social and physical health of consumers. The methodological basis of the research was foreign and domestic publications and analytical reviews on the problems of marketing intelligence using web analytics. The proposed approaches can be taken into account by the marketing services of domestic enterprises when conducting marketing intelligence. An example of Google Analytics examines the technology of marketing intelligence. It is concluded that the beginning of development of open methods of processing private data of users without their direct identification is positive. which would limit the interference with the privacy of people, leaving marketing intelligence possible, and would prevent its negative impact on people's lives.

Key words: marketing intelligence, site, Google Analytics, web analytics system, audience

Макара Оксана, доктор экономических наук, профессор, Восточноевропейский национальный университет имени Леси Украинки, кафедра финансов и кредита, г. Луцк 